\title{
Naim Stifan Ateek \\ A Palestinian Theology of Liberation: The Bible, Justice, and the Palestinian Conflict
}

(Maryknoll: Orbis Press, 2017), paperback, xix +172 pages

\author{
TODD WALATKA \\ twalatka@nd.edu \\ University of Notre Dame, Notre Dame, IN 46556
}

Naim Ateek is founder of the Sabeel Ecumenical Liberation Theology Center and an influential figure in the field of Palestinian liberation theology. A Palestinian Theology of Liberation offers a synthesis of themes in many of his previous works as well as a more detailed demonstration of his reading of Scripture. It expresses his passionate and prophetic plea for the oppressed Palestinian people in the Holy Land against dangerous and destructive religious ideologies. It represents a committed and uncompromising defense of non-violence as the only way forward toward genuine peace. Finally, it condemns systemic injustice and the failure of so many Christians throughout the world to attend to the suffering of the Palestinian people. However, it is also structurally shaped by a supersessionist theological vision.

Ateek's first chapter articulates the fundamentally anti-colonialist and antiZionist perspective of Palestinian liberation theology. Chapter two offers an historical account of the Palestinian people, and chapter three describes the 1948 Palestinian Nakba (catastrophe) as a human trauma, as an attempt to undermine Palestinian cultural and social identity, and as a challenge to faith, particularly in the face of biblical defenses of Zionism. Chapter four offers his analysis of important historical events of the last seventy years, including the Holocaust, the Six Day War, and the first Intifada. Chapters five through eight contain his constructive theological proposal. After a brief discussion of Jesus Christ as liberator (chapter 5), Ateek offers a lengthy engagement with the Old Testament (chapter 6), a call to understand the Bible in light of Christ and the commandment of love (chapter 7), and a vision of a just peace as central to Christian faith and to any resolution of the Palestinian-Israeli conflict (chapter 8). The final two chapters offer an account of the work of the Sabeel Center (chapter 9) and a clear synopsis of the major themes of the book (chapter 10). 
The core antagonist of the book is what one might call "settler theology," a theology which proclaims an exclusionary vision of the Land of Israel and erases any claim of the Palestinian people to their homeland. Ateek writes, "One of the many features of this [Zionist] enterprise has been the use of the Bible as a tool to claim that the land of Palestine belongs solely to the Jewish people. Such a claim is historically false and theologically unfounded. Liberating the scriptures from Zionism means understanding that the person of Jesus Christ reveals a loving God who desires the liberation of all people" (p. 11; my emphasis). A prominent theme of the book is his distinction between "inclusive" and "exclusive" religiosity and between a "tribal" and a "universal" conception of God (p. 81).

This distinction is key to Ateek's reading of the Bible, for it buttresses the theological and political critiques he presents, though it also ends up representing a form of supersessionism. Ateek celebrates certain texts in the Old Testament (such as Jonah, Ezekiel 47, and selected psalms, among others) on account of their supposed inclusivity and universalism. However, he views much of the Old Testament as overly exclusivist. In response to texts about violence and conquest, such as the destruction of the Amalekites, for example, Ateek is quite bold: "They are not morally edifying; they do not contain a word from God to us. Rather, they reflect primitive human understanding as well as the prejudice, bigotry, and racism of tribal societies. Categorically, in no way do they reflect the love of God for all people as revealed to us in Jesus Christ" (p. 48). Expanding out, it is unclear if his theology makes any room for the distinctiveness of the Jewish covenant, historically or today. He argues that the Torah is generally exclusionary (p. 81) and that Leviticus fails to be genuinely inclusive of non-Jews (p. 64). To underscore the pervasiveness of these points, he often simply lists texts-without discussing their context - to exemplify such exclusionary thinking within the biblical and Jewish traditions (pp. 56-58) and then contrasts them with the teachings of Jesus, presented as a model inclusive figure (pp. 90-92), and of Paul, presented as rejecting the ongoing relevance of the Mosaic Law (pp. 93-96). These sections are particularly problematic, as one is left with the impression of the biblical and later Jewish traditions as inherently xenophobic and exclusionary. In terms of the New Testament, the Jewishness of Jesus is not denied, but it also does not play any substantial, positive role. More generally, Ateek presents much of the Jewish religious tradition as illegitimate and superseded. That Ateek also finds a theological inclusivism in a text such as Jonah (the "heart of Old Testament theology" and the Old Testament's theological climax [pp. 76, 79]), does little to weaken his overarching supersessionist approach.

Most of those committed to improved Jewish-Christian relations will have a strongly negative response to the book. I recognize, as I noted, that it has serious exegetical and theological problems. Nevertheless, Ateek's book provides a challenge to readers who are deeply committed to both God's enduring covenant with the Jewish people and to the affirmation of God's preferential love for the vulnerable, ostracized, excluded, and oppressed. Do our theologies stand in service of exclusion and Palestinian dispossession? Are our theologies shaped by genuine empathy for the plight of the Palestinian people? What tools do we have for inter- 
preting Scripture in a way that promotes true peace? One, of course, would want to ask many questions to Ateek in return: what of the enduring Jewish covenant? What of Jewish longing for their homeland over the centuries?

Ateek's theological proposals reflect his attempt to interpret the Bible as liberatory for the Palestinian people and as supportive of justice and peace for all people. His commitment to non-violence is particularly noteworthy in this regard. His proposals also reflect the dangers and messiness of forging a theology in the midst of the Israeli-Palestinian conflict. His work is deeply problematic in certain ways, and yet it positively calls for an uncompromising commitment to a vision of God who "wills that people live in justice and love, in mercy and forgiveness, in peace and reconciliation" (p. 41). 